\title{
A new type of aeolian morphogenesis on volcanic shores (Iturup Island, Great Kuril Ridge)
}

\author{
Victor V. Afanasyev
}

\author{
Institute of Marine Geology and Geophysics FEB RAS, \\ Yuzhno-Sakhalinsk, Russia \\ *E-mail:vvasand@mail.ru
}

\begin{abstract}
PDF Rus
The main reasons for the formation of sediments excess in the coastal zone have been considered to explain the aeolian accumulation of soil close transfer on different types of shores. The grounds are presented for division of a new type of aeolian morpholithogenesis on volcanic shores associated with a large amount of pyroclastic material entering to the wave processing zone during explosive eruptions in the Middle - Late Holocene. It has been established that the age of such dunes correlates with the age of deposits of volcanic pumice and tephra, but it is not concern to well-known periods of high or low sea level.
\end{abstract}

\section{Keywords}

coastal dunes, explosive volcanic eruption, tephrochronology, subaerial beach, sea level, Iturup Island

For citation: Afanasyev V.V. A new type of aeolian morphogenesis on volcanic shores (Iturup Island, Great Kuril Ridge). Geosystems of Transition Zones. 2019, vol. 3, no. 4, pp. 423-427. (In Russian) https://doi.org/10.30730/2541-8912.2019.3.4.423-427

Для цитирования: Афанасьев В.В. О новом типе эолового морфогенеза на вулканогенных берегах (о. Итуруп, Большая Курильская гряда). Геосистемы переходных зон. 2019. Т. 3, № 4. С. 423-427. https://doi.org/10.30730/2541-8912.2019.3.4.423-427

\section{References}

1. Афанасьев В.В. Эволюция побережья дальневосточных морей в голоцене // Эволючия берегов в условиях поднятия уровня океана. М.: ИО РАН, 1992. С. 166-174.

2. Бадюкова Е.Н., Соловьева Г.Д. Рельеф приморских дюн как индикатор колебаний уровня моря // Вестник Москов. ун-та. Сер. 5, География. 1997. № 5. С. 10-19.

3. Бадюкова Е.Н., Соловьева Г.Д. Прибрежные эоловые формы и колебания уровня моря // Океанология. 2015. T. 55(1). C. 139-146. [Badyukova E.N., Solovieva G.D. Coastal eolian landforms and sea level fluctuations. Oceanology, 2015, 55(1): 124-130. https://doi.org/10.1134/s0001437015010014]

4. Ботвинкина Л.Н. Генетические типы отложений активного вулканизма. М.: Наука, 1974. 318 c.

5. Игнатов Е.И. Морфосистемный анализ берегов. М.; Смоленск: Маджента, 2006. 328 с.

6. Короткий А.М. Эоловый рельеф Приморья и сопредельных территорий Восточной Азии (палеогеографический аспект) // Геоморфология. 2007. № 4. С. 79-95.

7. Короткий А.М., Разжигаева Н.Г., Мохова Л.М., Ганзей Л.А., Гребенникова Т.А., Базарова В.Б. Береговые дюны - индикатор глобальных похолоданий (о. Кунашир, Курильские острова) // Тихоокеанская геология. 1996. Т. 15(1). С. 53-59.

8. Мелекесцев И.В. Новейший наземный и подводный вулканизм Курильской островной дуги // Новейший $u$ современный вулканизм на территории России. М.: Наука, 2005. С. 233-335.

9. Разжигаева Н.Г., Ганзей Л.А. Обстановки осадконакопления островных территорий 8 плейстоиене-голоиене. Владивосток: Дальнаука, 2006. 365 с. 
10. Aagaard T., Orford J.D., Murray A.S. Environmental controls on coastal dune formation; Skallingen Spit, Denmark // Geomorphology. 2007. Vol. 83(1-2). P. 29-47.

https://doi.org/10.1016/j.geomorph.2006.06.007

11. Afanas'ev V.V., Uba A.V., Ignatov E.I., Dunaev N.N., Leontiev I.O., Gorbunov A.O. Vetrovoy isthmus of Iturup Island - Holocene strait // IOP Conference Series: Earth and Environmental Science. IOP Publishing, 2019. Vol. 324(1). P. 012029. https://doi.org/10.1088/1755-1315/324/1/012029.

12. Porter S.C. Late Pleistocene eolian sediments related to pyroclastic eruptions of Mauna Kea Volcano, Hawaii // Quaternary Research. 1997. Vol. 47(3). P. 261-276. https://doi.org/10.1006/qres.1997.1892

13. Provoost S., Jones M.L.M., Edmondson S.E. Changes in landscape and vegetation of coastal dunes in northwest Europe: a review // J. of Coastal Conservation. 2011. Vol. 15(1). P. 207-226. https://doi.org/10.1007/s11852-009-0068-5

14. Szkornik K., Gehrels W.R., Murray A.S. Aeolian sand movement and relative sea-level rise in Ho Bugt, western Denmark, during the 'Little Ice Age' // The Holocene. 2008. Vol. 18(6). P. 951-965. https://doi.org/10.1177/0959683608091800

15. Tamura T., Kodama Y., Bateman M.D., Saitoh Y., Yamaguchi N., Matsumoto D. Late Holocene aeolian sedimentation in the Tottori coastal dune field, Japan Sea, affected by the East Asian winter monsoon // Quaternary International. 2016. Vol. 397. P. 147-158. https://doi.org/10.1016/j.quaint.2015.09.062

16. Tanino K. Environments of the formation of dunes at Shiriyazaki in the Shimokita Peninsula, Aomori Prefecture // The Quaternary Research (Daiyonki-Kenkyu). 2000. Vol. 39(5). P. 471-478. https://doi.org/10.4116/jaqua.39.471

17. Vries, de, S., Southgate H.N., Kanning W., Ranasinghe R. Dune behavior and aeolian transport on decadal timescales // Coastal Engineering. 2012. Vol. 67. P. 41-53. https://doi.org/10.1016/j.coastaleng.2012.04.002

18. Vries, de, S., Arens S.M., De Schipper M.A., Ranasinghe R. Aeolian sediment transport on a beach with a varying sediment supply // Aeolian Research. 2014. Vol. 15. P. 235-244.

https://doi.org/10.1016/j.aeolia.2014.08.001 